\title{
MEDITERRANEAN MIGRATIONS: REGIONALISMS VERSUS GLOBALISATION
}

\author{
MARTIN BALDWIN-EDWARds ${ }^{1}$
}

\begin{abstract}
This paper challenges the claim of globalisation as a cause of immigration into Southern Europe and, on an empirical basis, identifies regionalisation as being the primary issue, along with networked migratory patterns. However, the changing patterns of immigration do present challenges to both state and society. It is argued here that recent policy responses in Portugal, Italy and Spain have been inconsistent and irrational - reflecting more the 'securitisation' of migration than European reality. Earlier policy innovations are identified, by country and date: most of these have now been abandoned. It is suggested that all of Southern Europe has converged onto a statist, restrictionist model of immigration control that was formerly held only by Greece. The principal characteristics of this model are outlined, along with a migration flowchart and indicative data for migrant flows and sub-flows in Italy and Spain. In the final section, I try to show that the needs of the economy cannot be predicted, immigration cannot be controlled in the manner currently being enforced across Southern Europe, and attempts to do so will damage rather than improve economic productivity and growth. The concept of an accomodating immigration policy is advanced, whereby the state tries to manage the needs of both employers and potential migrants. Six guidelines for policy development are suggested - most of which have already been successfully carried out in the European Union. These are the following: migration in order to find a job; circular cross-border migration; EU level negotiation of readmission agreements; the need for a variety of migration-for-employment schemes; legal residence should not depend upon continuity of employment; and discreet legalisation will still be needed in Southern Europe.
\end{abstract}

Key words: Southern European immigration policies, regionalisation, globalisation.

Resumo - MigraÇõES NO MEditerRÂNeO: REgIONALISMOS VERSUS GLOBALIZAÇÃo. Este artigo põe em causa a ideia de que a imigração para a Europa do Sul se deve à globalização e, com base em fundamentos empíricos, aponta a regionalização, juntamente com o funcionamento em rede dos sistemas migratórios, como as causas fundamentais. Reconhece-se, porém, que as actuais transformações dos

1 Co-Director, Mediterranean Migration Observatory, Panteion University, Athens; General ANTIGONE (RAXEN Network), Greece. Emails: baldwin@panteion.gr and mbe@antigone.gr. 
padrões migratórios colocam alguns desafios bem reais aos Estados e às sociedades. Considera-se que as respostas por parte das autoridades políticas de Portugal, Espanha e Itália têm sido inconsistentes e irracionais - traduzindo a "securitização" da questão da imigração, mais do que a realidade europeia. São identificados, por país e por data, alguns aspectos inovadores de anteriores políticas de imigração - a maioria dos quais foi entretanto abandonada. Sugere-se que toda a Europa do Sul convergiu para um modelo de controle da imigração estatista e restritivo, que era anteriormente apanágio exclusivo da Grécia. São apresentadas as principais características deste modelo, juntamente com um mapa de fluxos migratórios e dados indicativos relativos aos fluxos e sub-fluxos em Espanha e Itália. Na última secção, procura-se demonstrar que é impossível prever as necessidades da economia, que a imigração não pode ser controlada da forma em que o tem sido nos diversos países da Europa do Sul e que as tentativas nesse sentido terão um resultado prejudicial, e não benéfico, sobre a produtividade e o crescimento económico. É sugerido o conceito de política de imigração acomodatícia como aquela em que o Estado procura satisfazer as necessidades tanto dos empregadores como dos potenciais migrantes. São sugeridas seis linhas orientadoras para o desenvolvimento de políticas futuras - a maioria das quais foi já implementada com sucesso no interior da União Europeia. São elas: migração em busca de emprego; migrações circulares transfronteiriças; negociação dos acordos de readmissão ao nível da UE; necessidade de uma diversidade de esquemas de "migração laboral"; não dependência da autorização de residência em relação à continuação do vínculo laboral; e continuação da necessidade de mecanismos discretos de legalização na Europa do Sul.

Palavras-chave : Políticas de imigração, Europa do Sul, regionalização, globalização.

Despite the grandiose claims of authors such as SASSEN (2000) and CASTLES and DAvidson (2000), identifying globalisation as an explanation of migration patterns, there has been little overall increase in global migration but rather, changed patterns impacting on certain regions (TAPINOS, 2000). Traditionally, migration into the Mediterranean has tended to focus on the North-South flows within the Basin: recently, new flows have had to be accommodated whilst the older type of flows continue. The argument contained in this paper is along the following lines:

1) That new migrations have made the Mediterranean region more complex and created new management problems - not only of migration, but also of international relations. The nature of immigration into Southern Europe is now a remarkable mix of nationalities and skill levels, only some of which could be considered part of a globalisation process;

2) That Southern European policies have lurched back and forth incoherently, reflecting underlying ambiguities, confusion of policy objectives with policy mechanisms, and an overall statist mentality inappropriate to the situation. Much of policy formulation in the last two years seems 
to have its inspiration in the US paranoia about terrorism: thus the recent policy changes are more ideology-based than pragmatic solutions to problems;

3) That the latest policy outcomes across Southern Europe seem to have converged onto a common model, which approximates the Greek case where little or no policy innovation has occurred in this area, and the result has been far from successful. This common model seems to have been derived partly out of the 'security' ideology, and partly from conformism with European/Schengen trends. However, the features of this model seem likely only to promote illegal migration, to retard the integration of long-term migrants, and to be very costly in both financial and social terms;

4) Finally, a policy solution is outlined, which follows a now-conventional view of the usual regulation of capitalist markets: that states cannot control migration, they can only manage it. Thus, government policy should accommodate market supply and demand relationships through a new flexible arrangement, rather than the old statist work permit approach. No state now has the capacity to predict labour market needs, or to react quickly to them: therefore, more open border policies are essential in the proper management of migration. Such a policy needs to be located in a regional or global framework, as it cannot easily be negotiated on bilateral bases.

In pursuing this argument, I have adopted the following structure for the paper: first, a brief discussion of globalisation versus regionalisation, along with evidence for the Southern European countries; secondly, an outline of the policy approaches across Southern Europe in the last decade, and in particular their previous innovations; thirdly, a common model is advanced, with an explanatory diagram; and, finally, I propose a framework of accommodating migration policies, and some suggestions on how their successful negotiation and implementation might be achieved.

\section{GLOBALISATION, REGIONALISATION OR NETWORKS?}

The claims by globalisation proponents that increased migration flows are the accompaniment to increased capital and information flows are hardly sustained by empirical evidence: rather, it seems that Europe has been the specific recipient of increased types of flows. Here, I present a tripartite categorisation of migration flows, devised to test the claims of globalisation theorists. The three categories are:

1) Regional migratory movements, defined as adjacent or proximate source and receiving countries, with no strong tradition of such flows. Such migrations could be cross-border or pendular; 
2) Global migratory movements, defined as long-distance migrations, probably temporary in nature (e.g. refugees or economic migrants);

3) Networked migration, defined as migratory movements following previous patterns, e.g. through colonial ties, family migration, bilateral country links, etc.

It will be noted that these migratory types are independent of legal form and of the mechanism of the migration itself; rather, they tend to focus implicitly on the personal costs and ease of migration.

Generally across Europe, there is little evidence of globalisation except in the case of the UK. Regionalisation, on the other hand, is a normal European pattern, along with networked migration. Looking at the Southern European countries, the following distribution of principal nationalities shown in Table 1 allows for some conclusions.

Table 1 - Dominant nationalities in Southern European countries, ranked.

Quadro 1 - Principais nacionalidades presentes nos países da Europa do Sul.

\begin{tabular}{|c|c|c|c|c|c|}
\hline \multirow{4}{*}{} & \multicolumn{2}{|c|}{ Portugal } & Spain & Italy & Greece \\
\hline \multirow{4}{*}{$\begin{array}{c}\text { Residence } \\
\text { permits 1999 }\end{array}$} & $\begin{array}{c}\text { Including permit } \\
\text { to stay 2001 }\end{array}$ & $\begin{array}{c}\text { Residence } \\
\text { permits 2001 }\end{array}$ & $\begin{array}{c}\text { Residence } \\
\text { permits 2000 }\end{array}$ & Census 2001 \\
\cline { 2 - 6 } $\begin{array}{c}\text { Nationality } \\
\text { Ranked }\end{array}$ & EU regime* & EU regime* & EU regime ** & Morocco & Albania \\
\cline { 2 - 7 } & Cape Verde & Cape Verde & Morocco & Albania & Bulgaria \\
\cline { 2 - 7 } & Angola & Brazil & Ecuador & Romania & Georgia \\
\cline { 2 - 7 } & Guinea-Bissau & Angola & China & China & USA \\
\cline { 2 - 7 } & USA & Guinea-Bissau & Peru & USA & Cyprus \\
\cline { 2 - 7 } & Sao Tome & USA & Dominican Rep. & Tunisia & Russia \\
\cline { 2 - 7 } & Mozambique & Moldova & Romania & Senegal & UK \\
\hline
\end{tabular}

* All migrants covered by EC law.

** Predominantly EU nationals but also including some 72,000 third country nationals.

Source: Data from national statistical institutes. Portugal: PeIXoto (2002); Spain: RAXEN (2002); Italy: ISMU (2002); Greece: own calculations from national database (2001).

For Portugal, the dominant pattern is of networked migration, but with the arrival of Ukrainians and some other Eastern Europeans in recent years - which might be considered either global or regional migrations. For Spain, there is a mix of regional (Morocco), networked (Peru, Ecuador, Colombia) and some global (China) migrations. Italy has predominantly regional (Morocco, Albania, Tunisia, Senegal, Romania) but also some global (USA, China) and some 
networked (Philippines) migrations. For Greece, it is again regional domination (Albania, Bulgaria, Georgia, Romania), with some networked (Cyprus, Russia) and some limited global (USA, Pakistan) migrations.

Thus, for all except Portugal, the dominant migratory flows seem to be regional, with significant but variable extents of networked migration, and relatively little global migration. This indicates a complex picture, where a 'one size fits all' policy is unlikely to be helpful.

\section{POLICY APPROACHES}

Although almost all European countries have undertaken regularisations of illegal residents, in various ways and at different times, it is in Southern Europe that this policy instrument is most important. In fact, so few immigrant workers were recruited by legal means in Portugal, Spain, Italy and Greece, that something around $80-90 \%$ of legally present Third Country National workers are legal solely because of regularisation programmes. Moreover, the non-application rate for Italy's various legalisations is estimated at 20-60\% (BRUCKER et al., 2001: 16); in Spain, the non-renewal rate of immigrants legalised in 1992 was estimated at around $50 \%$ by 1995 when their two-year permits had expired (MENDOZA, 2000: 7). In Greece, the ratio of legal to illegal workers, at any one time, is estimated as varying between 1:3 and 1:6 (BALDWIN-EDWARDS, 2004). Thus, the absence of legal labour recruitment in Southern Europe has resulted in legalisation programmes constituting the principal policy mechanism; we might also add that this policy failure has been an important part of the expansion of the informal sector in these countries, staffed increasingly by illegal immigrants (BALDWIN-EDWARDS and ARANGO, 1999).

Despite the variety, and limited success of innovative policy in Portugal, Spain and Italy, all of those innovations have now been overturned. In particular, we should note the following:

- Multiple and flexible visa arrangements (Portugal, 2001 law)

- Stay permit - via a continuous legalisation process (Portugal, 2001 law; Spain, law 4/2000)

- Sponsored migration for employment search (Italy, 1998 law)

- Duties of state agencies in dealing with applications, e.g. time frame, grounds for refusal, etc. (Portugal, 2001 law; Spain, law 4/2000)

- The right to family reunification (Italy, 1998 law)

- Rights of illegal immigrants (Spain, law 4/2000)

Most of these have now been removed by subsequent legislation. Since the September 11 terrorist attacks, Southern Europe has become obsessed with a security paradigm that has little to do with the European reality (BIGO, 2002). The one Southern European country that has attempted no innovative policies, 
and actually failed to maintain even a semblance of order in managing its immigrant population, is Greece. The lack of legal channels for entry, now well established as a principal cause of illegal immigration across Europe (SCANLAN, 2002), was accompanied by poor border and internal controls, and no legalisation programme until 1997. The situation remains highly unsatisfactory even today, with the threat of mass deportations - despite the opinion of the Ombudsman that these may be illegal - and immigrants left in limbo, between legality and illegality.

Thus, it seems somewhat strange that the rest of Southern Europe should have adopted a model of immigration that broadly resembles the Greek one. The model emphasises the integrity of national borders, places severe restrictions on the number (quota) of immigrants potentially to be admitted, requires employment contracts before entry, gives out mainly short-term permits, and increasingly undercuts any rights which immigrants might have in law. This model also is increasingly reliant upon expulsions without legal process, in order to solve the problem of illegal residents. Until now, Greece has been the only EU country that regularly expelled large numbers - typically 150-270,000 expulsions per year.

Below, I identify the main characteristics of contemporary immigration control in Southern Europe.

Characteristics of the new Southern European immigration policies

- Pre-entry authorisation in foreign consulate with guaranteed job (under quota set by the Labour Ministry)

- Short permits (1 or 2 years)

- Continuous employment needed to renew permits

- Reduction or removal of many legal rights (e.g. in Spain, new law requires judges to expel immigrants charged, not convicted, with a crime carrying a prison sentence; also in Spain, expulsion of immigrants with permit applications; in Italy, expulsion of applicants for legalisation if their applications were not accepted)

- Aggressive police and other measures to detect illegal immigrants (in Spain, use of airline data on unused return tickets; Spanish deal with IOM to involve NGOs in reporting illegal migrants), along with attempts to expel more migrants

- More secure borders, new technology, more helicopters, personnel and training. Also coastguard patrols (Spain, Portugal, Italy and UK) - failed and expensive. Costs very high, e.g. Greece spent $€ 600 \mathrm{~m}$ in 2002 on border measures.

- More readmission agreements with sending countries, and very recent attempts to make sending countries construct an emigration policy, preventing departures.

If we consider how this immigration policy model operates, in terms of flows, the following diagram (Fig. 1) proves useful. In Figure 1, I try to show how migration flows interact with the formal and informal economy of the host 
country. ${ }^{2}$ Thus migrants can enter the formal economy only as legally recruited labour, and in some cases as beneficiaries of family reunification; asylum seekers are generally denied the right to work, but in any case are very small numbers in Southern Europe. The principal source of black economy workers is provided by the very large flows of tourists (along with 'students', in much smaller numbers). Thus, overstayers and others illegally working constitute the greater part of the immigrant black economy participation. Illegal migration itself seems to be important with two regional migrant groups - Albanians and Moroccans - who are more likely to have entered without a visa. Only in the case of Greece, where Albanians constitute some 65\% of non-EU immigrants, is the illegal migration route a normal pattern of labour market incorporation.

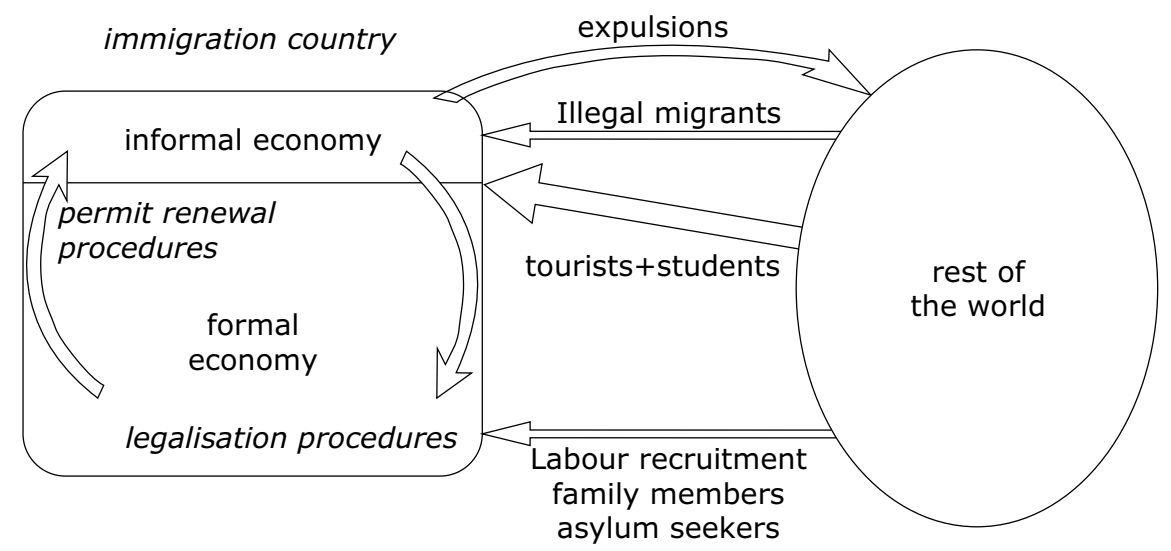

MIGRATION POLICY FLOWCHART FOR

SOUTHERN EUROPEAN STATES

(c) M. Baldwin-Edwards 2003

Fig. 1 - The new Southern European immigration policy.

Fig. 1 - A nova política de imigração na Europa do Sul.

There are a limited number of policy options for the state's response to illegal migrants in its economy. These are:

- Toleration of their illegal presence and employment;

- Attempts to coerce them into legality; and

- Expulsion from the territory.

In practice, every country uses a combination of all three instruments, but with rather different emphases. Greece has been the outlier, with expulsion and toleration uneasily co-existing as the main policy, although since 1997 some legalisation attempts have been made. Spain, Portugal and Italy have relied

2 For a detailed analysis of this, see JAHN and StraubHaAR (1999). 
more upon a mix of legalisation and toleration; more recently, they have been trying to develop expulsion as a serious option.

In Figure 2, these policy options are shown in a cyclical pattern, which I believe to more accurately represent reality. Legalisation attempts have a shortterm effect, because all southern countries favour short-term statuses; the requirements laid down for renewal of permits - continuous employment, complete social insurance contribution records, various other bureaucratic demands - along with bureaucratic ineptitude in processing applications, push the legalised migrants rapidly back into illegality. This is represented by the circular arrows in the left-hand box.

Migration flows also have something of this cyclical pattern, if expulsions and deportations are used significantly. Thus far, only Greece has exhibited this aspect of the model, but other southern countries are attempting to emulate it.

\section{Empirical data in the flowchart}

The strongest single piece of evidence has been revealed only recently by the Spanish government (MNS, Aug. 2003). Using annual data of arrivals and departures of non-residents, by nationality, they conclude that in 2002 some 460,000 South Americans did not leave Spain, and some 680,000 Africans remained illegally. If correct, these data show conclusively that legal entry is the normal pattern of illegal migration. However, the figures given for visas granted over one year are absurdly high (18 million!) and at odds with data obtained for the previous year. Below, I give some approximate data for Italy and Spain, 2001-2002, which demonstrate the continuing informality of labour recruitment, migration flows, and labour market participation. They also suggest the circularity of the legalisation processes, and the consequences of restrictive granting of permits.

Table 2 - Statistical data for migrant flows/processes in Italy and Spain, 2001-2002

Quadro 2 - Dados estatísticos relativos aos fluxos/processos migratórios em Espanha e Itália, 2001-2002

\begin{tabular}{|c|c|c|c|}
\hline & & Italy & Spain \\
\hline \multirow{3}{*}{ INFLOWS } & Total visas & $1,000,000$ & 670,000 \\
\cline { 2 - 4 } & Tourism or study & $\mathrm{n} / \mathrm{a}$ & 150,000 \\
\cline { 2 - 4 } & Recruited labour & 65,000 & 13,000 \\
\cline { 2 - 4 } & Illegal entry detected & 31,000 & 16,000 \\
\hline \multirow{2}{*}{ OUTFLOWS } & Expulsion orders & 58,000 & 22,000 \\
\cline { 2 - 4 } & Orders enforced & 21,000 & 3000 \\
\hline \multirow{3}{*}{ ILLEGAL STATUS } & Regularisation applicants (latest data) & 700,000 & 615,000 \\
\cline { 2 - 4 } & Permit renewal applicants & $\mathrm{n} / \mathrm{a}$ & 335,000 \\
\cline { 2 - 4 } & Estimated no. undocumented & 800,000 & 460,000 \\
\hline
\end{tabular}

Sources: MNS (various dates); ICMPD (2003); Statewatch (2002); Sciortino and Pastore (2002). 


\section{TOWARDS A POLICY FRAMEWORK}

The dominant mode of immigration management, i.e. pre-entry authorisation through employment, or through labour quota agreements, have been shown to be ineffective and unable to respond to market demands - either from employers or migrants looking for work. The state is unable to predict labour market needs, owing to information deficit, a rapidly changing economic environment, and slow, inefficient bureaucratic processes. In reality, the informal sector exists largely because of the labour market control mechanisms of Southern European state systems. Two recent problems stand out as being indicative: in Spain, the recruitment quota was set too high (apparently because they forgot that recently legalised immigrants were more likely to fill vacancies); in Italy, pensioners demonstrated against Berlusconi's immigration restrictions, as they needed to employ immigrants for elderly care and other domestic services. Thus, Italy now has the biggest legalisation ever undertaken in Europe, with 700,000 applicants.

Bilateral agreements to return illegal migrants have proven less than effective, especially as the EU has to date not concluded any readmission agreements with a significant sending country. More recent attempts to coerce, even pay, sending and transit countries to control emigration seem to be more successful: however, the implications of this have not been talked through. One of the fundamental policies of the former Communist bloc was the prevention of emigration by their nationals, by means of the 'Iron Curtain': is this now Europe's own policy, to recreate an Iron Curtain with neighbouring countries?

For Bhagwati, it is evident that "borders are beyond control and little can be done to really cut down on immigration" $(2003$ : 99, 104). He also adds that governments should reorient their policies from trying to stop migration towards coping with it. To this we might add, that given the neo-liberal emphasis on market forces with movement of capital and goods, in the context of stagnant European economies and market rigidities, relatively free movement of workers is likely to assist Europe's economic recovery. Protectionism has been successful only as a short-term policy for long-term objectives: this hardly seems true of immigration restrictions. Thus a radical shift is needed in the management of immigration - away from the security and control paradigm of right-wing politicians and towards economic development in both the first and third worlds. I make some preliminary suggestions below.

The following broad outline of policy is suggested here:

1) Abandonment of labour recruitment, except for skilled professionals and seasonal unskilled workers. The unskilled sector, which is the major part of immigration into Southern Europe, is currently being filled by illegal migrants. The state can neither predict, demand, nor respond rapidly to it, therefore it should adopt an accommodating policy. This is most easily achieved by allowing migration for job seeking, within certain conditions; 
2) There should be a facilitation of non-EU cross-border movements, so that temporary workers and seasonal workers can look for employment, and return to their home country if they fail to find such (circular migration). The current policies force migrants to stay longer in the receiving country, and may actually create permanent migrants owing to the difficulty of return even to nearby countries;

3) The negotiation of agreements should not be done at a national level. The negotiating power at this level is too weak, and it requires a regional collaborative agreement to satisfy all parties. The asymmetrical structures set up by the EU have seriously damaged intra-Mediterranean relations, and the Barcelona Process has offered almost nothing to North Africa. The Berne Process, which was started in 2001, looked to be a serious attempt to consider new international regulation of migratory movements;

4) There should be a variety of migration-for-employment schemes, enabling individuals and employers to choose the most appropriate. The primary consideration should be of employers' needs, whilst recognising international and domestic legislation of workers' and migrants' rights;

5) Legality should not be contingent upon continuous employment, which is an unrealistic aim even for the native workers in modern labour markets. Rather, it should be linked to objective criteria of job search and time limits on such; and

6) Illegal migrants and workers will still continue, not least because of the large informal economies in Southern Europe. Concealed legalisations (the "Contingente" in Spain) have proven far more effective in managing the problem, as they do not attract subsequent illegal migrants through the publicity. Proper policy management should hardly be visible, instead of the regular fiascos that are observed across the region. However, the fight against trafficking is now a serious issue, largely caused by poor policy in the last twenty years. Legal routes to migration will cause the most damage to traffickers, and begin to rectify the balance needed for a rational and humane approach to migration.

\section{REFERENCES}

BALDWIN-EDWARDS, M. (2004, forthcoming in Italian) - The management of illegal migration in Greece, 1991-2002. Università di Firenze, Italy.

BaldWin-EdWARds, M.; ARANGo, J. (1999) - Immigrants and the Informal Economy in Southern Europe. Frank Cass, London \& Portland, Oregon.

BIGO, D. (2002) - Security and Immigration: towards a critique of the governmentality of unease. Alternatives, 27: 63-92. 
Brücker, H.; Epstein, Gil S.; McCormick, Barry; Saint-Paul, Gilles; Venturini; Alessandra; ZimmerMANN, Klauset al. (2001) - Managing Migration in the European Welfare State. Presented at the conference 'Immigration Policy and the Welfare State', Fondazione Rodolfo DeBenedetti, Trieste, 23 June, Milan. Mimeo, 182 pp. (The whole book is downloadable free (as at 23/11/03); the file is $720 \mathrm{~kb}$, at: www.frdb.org/images/customer/copy 0 paper1 23 jun01.pdf.

Bhagwati, J. (2003) - Borders Beyond Control. Foreign Affairs, Jan./Feb.: 98-104.

Castles, S.; Davidson, A. (2000) - Globalisation and the Politics of Belonging. Routledge, London \& New York.

CodinI, E. (2002) - Aspects of Legislation. In ISMU. The Seventh Italian Report on Migrations, 2001. Fondazione per le Iniziative e lo Studio sulla Multietnicità, Milan: 23-30.

Di Pascale, A. (2002) - The New Regulations on Immigration and the Status of Foreigners in Italy. European Journal of Migration and Law, 4: 71-77.

FASANO, L.; ZuCCHINI, F. (2002) - Local implementation of the consolidated law on immigration. In ISMU. The Seventh Italian Report on Migrations, 2001. Fondazione per le Iniziative e lo Studio sulla Multietnicità, Milan: 31-44.

Gortázar, C. (2002) - Spain: Two Immigration Acts at the End of the Millenium. European Journal of Migration and Law, 4: 1-21.

ICMPD (2003) - Study on Return. A Swiss Perspective. International Centre for Migration Policy Development, Vienna

ISMU (2002) - The Seventh Italian Report on Migrations, 2001. Fondazione per le Iniziative e lo Studio sulla Multietnicità, Milan.

Jahn, A.; StraubhaAR, T. (1999) - A Survey of the Economics of Illegal Migration. In BaldwinEdWARDS, M.; ARANGo, J. -Immigrants and the Informal Economy in Southern Europe. Frank Cass, London \& Portland, Oregon: 16-42.

MendozA, C. (2000) - The Role of the State in Influencing African Labour Outcomes in Spain and Portugal. Working Paper 3. Center for Comparative Immigration Studies (CCIS), University of California, San Diego.

MNS (various dates) - Migration News Sheet. Migration Policy Group, Brussels.

NAscimbene, B. (2000) - The Regularisation of Clandestine Immigrants in Italy. European Journal of Migration and Law, 2: 337-359.

OECD (2003) - Trends in International Migration, 2002. OECD, Paris.

Peixoto, J. (2002) - Strong market, weak state: the case of recent foreign immigration in Portugal. Journal of Ethnic and Migration Studies, 28 (3): 483-497.

RAXEN (2002, under embargo) - Legislation Report, 2002. Raxen Network, Spanish NFP. European Union Monitoring Centre on Racism and Xenophobia (EUMC), Vienna.

Sassen, S. (2000) - Guests and Aliens. Free Press, New York.

SCANLAN, S. (2002) - Report on Trafficking from Moldova: Irregular Labour Markets and Restrictive Migration Policies in Western Europe. Migrant, International Labour Office (ILO), Geneva.

SCIORTINO, G.; PASTORE, F. (2002) - Immigration and European Immigration Policy: Myths and Realities. Working Paper. FIERI, Torino, Italy.

Paper available at: http://www.mronca.it/Fieri/papers/sciortino_immigration_myths.doc.

Statewatch (2002) - Statewatch Bulletin, Nov-Dec, 2002. Statewatch, London, UK. Available at: 
http://www.statewatch.org.

TAPINOS, G. (2000) - Globalisation, regional integration, international migration. International Social Science Journal, 165: 297-306.

URbano DE SousA, C. (2002) - The New Portuguese Immigration Act. European Journal of Migration and Law, 4: 49-69. 